\title{
Information searching behavior in the Internet age: A users' study of Aligarh Muslim University
}

\author{
Mohammad Nazim
}

Central Library, Banaras Hindu University, Varanasi 221005, India

\begin{abstract}
Summary
This study reports the results of a survey conducted at Aligarh Muslim University (AMU) to determine the extent to which Internet users are aware and make use of the Internet resources and services. The study examines the information searching behavior of Internet users. A questionnaire and follow-up interviews with the postgraduate students, research scholars and academic staff were conducted to collect data. A total of 489 questionnaires were distributed to the selected sample of eight faculties; 405 valid samples were collected. The data were analyzed according to the background of Internet users, Internet information searching behavior, use of Internet resources and services, quality of Internet information, problems of the Internet access and need for Internet literacy. The study found that the majority of respondents had a 5 year history of Internet access. The academic staff spent more time on the Internet than the students and research scholars. Although Internet search engines were the preferred information searching tool, other methods such as databases, gateways and World Wide Web (WWW) were also used. Online journals and databases were the preferred information sources among the Internet users. Respondents chose e-mail, WWW and search engines as important Internet services. About $60 \%$ of respondents believed that the good quality of information on the Internet made it a useful tool for education and research. Slow speed, lack of training and information overload were indicated as some of the factors affecting Internet usage. Further, recommendations are made to improve the use of Internet, including a well-planned Internet literacy program and preparation of subject gateways.

(c) 2007 Elsevier Ltd. All rights reserved.
\end{abstract}

\section{Introduction}

For centuries printed information sources have been used either by users purchasing them or by using them through libraries and information centers. The trend began to change about four decades ago with the introduction of

E-mail address: nazim@sify.com computers in information processing and retrieval, and there has been a dramatic change over the past few years. 'Recent developments in information and communication technologies, especially the Internet and the Web, have brought significant changes in the ways we generate, store, access and make use of information' (Chowdhury \& Chowdhury, 2003). The Internet, a collection of interlinked computer networks or a network of networks, plays a key role in the access of information resources to support 
learning and teaching in academic atmosphere. 'Use of Internet to support learning and teaching is growing exponentially, as more educational organizations are recognizing the potential that it offers' (Nazim \& Chowdhary, 2004). Sources of information and other opportunities available via the Internet are increasing exponentially over the years and various programs have been developed to help users find their way about. This is because of the steady increase in the use of the Internet for education and research. With the development of more sophisticated customized searching tools, it has become easier to obtain required information through the Internet.

In addition to providing access to readily available information, the Internet also enables individual users to reach other people and institutions all over the world and exchange or obtain information. Anyone who has access to the Internet can make use of this network to search for information or to communicate via electronic mail (e-mail), mailing listserv, news groups, chat boxes, Wide Area Information Server (WAIS) and the World Wide Web (WWW).

The Internet has some incredible electronic libraries ready for users. On a small screen of the personal computer this digital world of the library is available. The digital format of this library consists of various electronic resources, such as electronic books (e-books), electronic journals and electronic reports. Institutional repositories/ archives are one of the important contributions of present Internet technology. 'A new class of digitized documents has been added to the electronic resources category, comprising those documents either originally published in print or other formats converted into the digital format' (Asemi, 2005). Now most of the popular newspapers and magazines have eversions providing full text of news items and featured articles. Today, the Internet has become a major source of information for a growing number of people, especially for the academic community (Spink, Bateman, \& Jansen, 1999).

As a result of ever growing information sources on the Internet, it has become difficult to ascertain the quality and authenticity of such information. In addition, a user or information searcher needs to have basic skills to find relevant information in the Internet's ocean of information. Therefore, it is essential for the information professionals to study the information searching behavior of academic communities in this Internet age.

\section{Problem statement}

Library resources, services and operations have been tremendously influenced by rapid technological innovations over the years. The Internet has virtually provided a new dimension to every area of library operations. Librarians world wide have been utilizing the Internet to enhance collections, expand services and improve operations. Internet resources and services, such as e-mail, online public access catalogues, publishers' catalogues, online journals, e-books, multimedia encyclopedias and dictionaries, are becoming useful collection-building tools in many libraries, especially academic libraries. Aligarh Muslim University (AMU) has also been added to a large number of such resources, which are accessible through central library, computer center and some faculties/departments. There- fore, it necessitates the regular study and development of new facilities to maximize the use of the Internet services by the users for education and research. The rapid growth of Internet use in the AMU has created a need for a users' study to investigate the quality of search requirements, users' searching habits and the problems encountered when using Internet resources and services.

\section{Review of related studies}

Many studies have examined the information searching behavior of Internet users. This study attempts to cover a number of works that go beyond discussions of the information searching behavior itself, and into its applications to closely related topics, such as patterns of information searching behaviors and uses of the Internet.

Studies on the information searching behavior of Internet users in India include that of Mahajan and Patil (1999), who carried out a study examining the purpose of Internet use by research workers at Pune University. They found that researchers used Internet primarily for conducting literature search. Bavakutty and Salih (1999) conducted a study at Calicut University which showed that students, research scholars and teachers used the Internet primarily for the purpose of study, research and teaching.

Naushad Ali (2000) conducted a study at AMU, Aligarh. The study showed that more than $50 \%$ of the respondents were satisfied regarding the amount of time allowed on the Internet, but dissatisfied with the staff's cooperation and with the unavailability of reservations. The majority of the respondents were also unhappy with the number of nodes available. Chandran (2000) conducted a study into the use of Internet resources and services in S.V. University, Tirupathi, indicating that more than $56 \%$ of respondents used the Internet to access information. They found that the majority of respondents used the Internet, Web and e-mail services. A survey of use of the Internet facility at the Guru Nanak Dev University, Amritsar, was conducted by Kaur (2000). This survey indicated that all respondents used the Internet to send e-mail and $82 \%$ for Web browsing. More than $60 \%$ of the respondents used the Internet for primary information, 38\% for secondary and only $15 \%$ used it for consulting OPACs.

Mahajan (2006) conducted a study on Internet use by researchers in Punjab University, Chandigarh, which analyzed how the convergence of information and communication technologies, as embodied by the Internet, has transformed the present day society into a knowledge society. The respondents considered the Internet the most valuable computer technology currently available to society.

Internationally, studies on the information searching behavior of Internet users have also been done. Singh (1998) presented the results of a study on the use of Internet by the librarians in Malaysia. The findings revealed that $90 \%$ of the respondents, most of whom were recent users of $t$ he Internet, used it for work related purposes. A study Becker (1998) conducted on the Internet use of public and private school teachers in the US indicated that $90 \%$ of the respondents had Internet access. The majority of the teachers (59\%) had Internet access at home and a majority of the teachers $(68 \%)$ used the Internet to find information resources for preparing their lessons. 
Voorbij (1999) examined the use of the Internet amongst students and academicians in The Netherlands. The study revealed that students and academicians faced many problems while searching general, factual, ephemeral or very specific information.

Laite (2000) presented the results of a survey on Internet use of 406 graduate and undergraduate students from Shippensburg University. He found that the majority of graduate and undergraduate students used the Internet 1-2 times per week. E-mail was found to be the most used Internet service as $100 \%$ of the graduate and undergraduate students used it.

Kalichman et al. (2002) conducted a survey on the Internet access and use for health information among people living with HIV-AIDS. They found that the majority of respondents were unaware of the availability of health information on Internet.

Spink and Jansen (2004) discussed the changes in Web search trends from 1997 to 2003 that explored how people search the Web. They pointed out some patterns and trends in general Web searching.

Akporido (2005) investigated Internet usage patterns in a Nigerian suburban setting-Abraka Delta State. Findings revealed the personal characteristics of the respondents, different aspects of their Internet use, such as duration of Internet usage access time, motivation for using the Net, search engines employed, Internet skills acquisition, frequency of Internet use, evaluation of Internet information content, problems encountered while using the Internet as well as way forward. Badu and Markwei (2005) conducted a study to find the extent of awareness and use of the Internet and its resources by academic staff and postgraduate students of the University of Ghana. The main findings indicated that both staff and students were fully aware of the Internet and most of its services. The study established that e-mail was highly used by both staff and students. Both staff and students found the Internet a very useful resource. The main reason for non-use of the Internet was inadequate training. Both staff and students needed appropriate education and training to ensure effective use of the Internet in all their academic pursuits.

A survey of 81 users of a Cyber cafe owned and run by the Delta State University, Abraka, was conducted by Igun (2005) to examine the self-reported level of Internet skills. The results showed that $71 \%$ of respondents rated their Internet skills between average and very high; 78.8\% acquired their Internet skills either online or through teaching by colleagues or friends. WWW skills were the most sought after additional skill (73\%). Continuing education and self-study were the most preferred ways to acquire new skills. Asemi (2005) conducted a survey on the search habits of Internet users at the Medical University of Isfahan (MUI) to find the search requirements related to the use of the Internet information. Results showed that all the respondents were using the Internet frequently because all faculties have provided connection to the Internet. He found that the researchers of MUI were getting quality information through the Internet. Researchers used the Internet in different ways, such as accessing to online journals, downloading software or text, chatting, discussion, e-mail services and for finding related references.
The specific aspects of the present study address the following objectives:

(1) To study the use pattern of the Internet by the students, research scholars and academic staff in AMU.

(2) To find out the extent of use of the Internet.

(3) To evaluate the search strategies of the Internet users.

(4) To assess users' satisfaction with regard to Internet resources and services.

(5) To identify the problems faced by the Internet users.

\section{Research design}

AMU is located in the city of Aligarh, Uttar Pradesh, Northern India. Modeled on the University of Cambridge, it was among the first institutions of higher learning set up in British India. The university grew out of the work of Sir Syed Ahmad Khan who in the aftermath of the Indian Rebellion of 1857 felt that it was important for Muslims to gain a modern education and become involved in the public life and government services in India at that time. Raja Jai Kishan helped Sir Syed a lot in establishing this university. In 1875, Sir Syed founded the Muhammadan Anglo Oriental College in Aligarh, based on Oxford and Cambridge Universities in England. His objective was to build a college in tune with the British education system but without compromising its Islamic values. The college was originally affiliated with Calcutta University and was transferred to the Allahabad University in 1885. The AMU established by the Aligarh Muslim University Act of 1920 evolved out of this college.

It was the first purely residential educational institution set up either by the government or the public in India. Over the years it gave rise to a new educated class of Muslims who were active in the political system of the British Raj, and who would serve as a catalyst for change among not only the Muslim population of India but of the entire subcontinent.

The university has 12 faculties, namely agricultural sciences, arts, commerce, engineering and technology, law, life sciences, medicine, management studies and research, science, social sciences, technology and unani medicine. Currently, the university has almost 30,000 students and over 2000 faculty members with over 80 departments of study. It continues to function as an important education institution in India and draws many students of foreign countries, especially Africa, West Asia and Southeast Asia. (Office of the Controller of Examination, 2006).

The university has its own telecommunication setup, a press, a most modern network system, a computer center and a university library system with a central library (Maulana Azad Library). Internet facilities are available for staff, research scholars and students in the central library, computer center and some faculties and departments. The focus of this article is the information searching habits of Internet users at $\mathrm{AMU}$ in order to find the status of information searching nature.

The present study covers postgraduate students, research scholars and academic staff of eight faculties. There are 12 total faculties on the campus of the university, out of which questionnaires were distributed to the respondents of agricultural sciences (FAS), commerce (FC), engineering and technology (FET), law (FL), medicine (FM), management 
studies and research (FMS), science (FS) and social sciences (FSS). All the faculties could not be covered due to time and financial constraints. In order to have a comprehensive understanding of information searching pattern of Internet users of AMU, a survey was designed and distributed among postgraduate students, research scholars and academic staff of the selected faculties. The survey was designed to assess the skill levels and competency of the Internet users, information searching behavior, users' evaluation of Internet resources and services and users' satisfaction with regard to Internet resources and services.

A total of 489 questionnaires were distributed to the randomly selected sample. To ascertain the real users and non-users of the Internet, respondents were first asked about their familiarity with the use of computers and the Internet. All the respondents selected for the sample were familiar with the use of computers and the Internet.

\section{Results}

\section{Response rate}

There was a high response rate from the questionnaires administered to the selected sample. Out of 489 ques- tionnaires distributed, 405 valid questionnaires were collected from the students (201), research scholars (102) and academic staff (102) of the faculties selected for the study. Faculty-wise responses from the Internet users are shown in detail in Table 1.

\section{History and experience of Internet use}

When studying the history of Internet use, it was observed that the majority of respondents (58\%) had a 2-5 year history of accessing the Internet, while only $10 \%$ had used the Internet for longer than 5 years. About $8 \%$ of the respondents started to access the Internet within 1 year of availability. It is interesting to note that academic staff had a longer history of using the Internet than students and research scholars. As Figure 1 shows, 21\% of academic staff used the Internet for more than 5 years, whereas only $9 \%$ of students had the same experience of Internet use.

Respondents were asked to determine how they learned to use the Internet. The results (Table 2 ) show that Internet users started to use Internet in a very informal way, such as self-instruction and learning by doing, as reported by $56 \%$ of respondents. Thirty-seven percent of respondents learned from colleague or friends; only $4 \%$ of respondents learned

Table 1 Faculty-wise response from the Internet users.

\begin{tabular}{|c|c|c|c|c|c|c|c|c|}
\hline \multirow[t]{2}{*}{ Faculty } & \multicolumn{2}{|c|}{ Students } & \multicolumn{2}{|c|}{ Research scholars } & \multicolumn{2}{|c|}{ Academic staff } & \multirow[t]{2}{*}{ Total Q. dis. } & \multirow[t]{2}{*}{ Total Q. rec. } \\
\hline & Q. dis. & Q. rec. & Q. dis. & Q. rec. & Q. dis. & Q. rec. & & \\
\hline FAS & 25 & 19 & 13 & 11 & 15 & 14 & 53 & 44 \\
\hline FC & 21 & 16 & 16 & 15 & 10 & 08 & 47 & 39 \\
\hline FET & 34 & 29 & 17 & 13 & 21 & 17 & 72 & 59 \\
\hline $\mathrm{FL}$ & 22 & 17 & 09 & 07 & 08 & 07 & 39 & 31 \\
\hline FM & 26 & 21 & 14 & 13 & 21 & 15 & 61 & 49 \\
\hline FMS & 29 & 27 & 05 & 05 & 07 & 06 & 41 & 38 \\
\hline FS & 42 & 33 & 21 & 17 & 19 & 16 & 82 & 66 \\
\hline FSS & 45 & 39 & 25 & 21 & 24 & 19 & 94 & 79 \\
\hline Total & 244 & 201 & 120 & 102 & 125 & 102 & 489 & 405 \\
\hline
\end{tabular}

Q. dis.: questionnaires distributed and Q. rec.: questionnaires received.

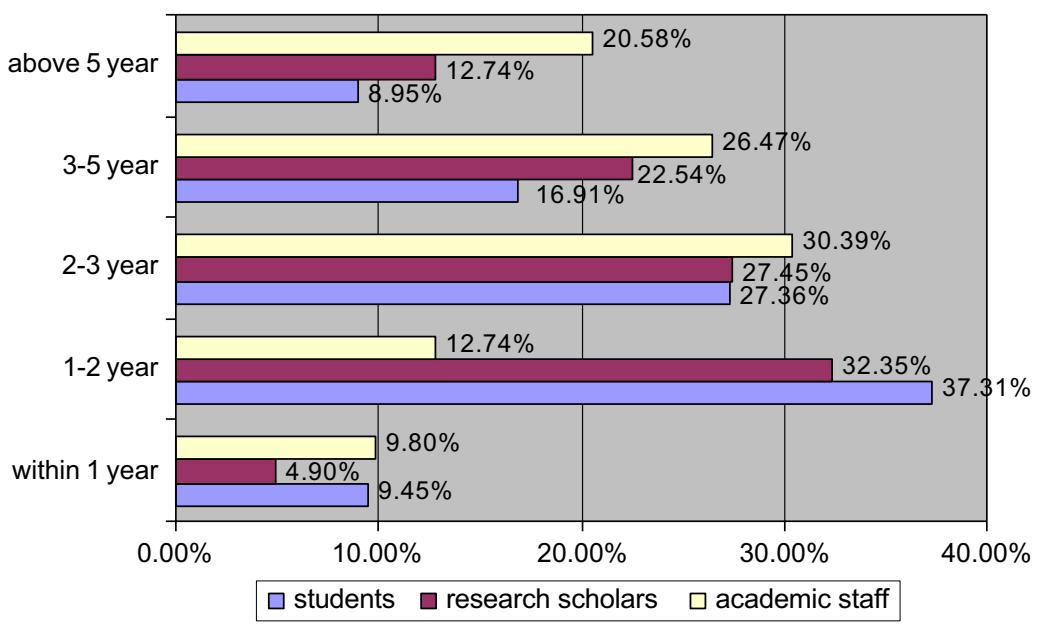

Figure 1 Internet use history. 
through training courses and $6 \%$ by reading publications on how to use the Internet.

\section{Locations for accessioning the Internet}

The respondents of all of the faculties covered in the study had access to the Internet through the computer center and departments. It is important to point out that few departments provided Internet access to students and research scholars, resulting in their use of computer centers or Internet cafes for access. In response to the growing demand for the Internet, the central library has recently started offering an Internet facility for students and research scholars.

When respondents were asked to indicate the preferred locations to access the Internet, $55.56 \%$ (Figure 2) of respondents chose the computer center, about $18 \%$ accessed at the central library and $19 \%$ at their concerned departments. Internet cafes were popular among the respondents when Internet facilities were not easily available in the university. But with the availability of Internet facilities in the university campus, only $7 \%$ of respondents chose to visit

Table 2 Methods of learning to use the Internet.

\begin{tabular}{llr}
\hline Methods & $\begin{array}{l}\text { Number of } \\
\text { respondents }\end{array}$ & \multicolumn{1}{l}{$\%$} \\
& & 32.35 \\
Discussion with colleague & 131 & 56.54 \\
Self-instruction & 229 & 6.41 \\
Learning material & 26 & 3.22 \\
Training courses & 13 & 1.48 \\
No answer & 06 & 100.00 \\
Total & 405 & \\
\hline
\end{tabular}

Internet cafes during the closing hours of the Internet facility on campus.

Departments and computer centers were the most frequently used locations for the academic staff as shown in Table 3, whereas students chose to go to computer centers or the central library, where they are allowed $1 \mathrm{~h}$ of Internet access a day. It may be noted that the majority of respondents (10\%) who visited Internet cafes were students. Only $4 \%$ of research scholars and academic staff reported accessing the Internet at Internet cafes.

\section{Time spent on the Internet}

The survey gathered information to determine the extent of Internet use. As Figure 3 illustrates, 36.56\% of respondents spent more than $8 \mathrm{~h}$ on the Internet each week, whereas $6 \%$ fulfilled their information requirements within $2 \mathrm{~h}$. It may be noted that $31.36 \%$ of respondents spent an average of $1 \mathrm{~h} \mathrm{a}$ day using the Internet.

Table 4 exhibits the time spent on the Internet according to academic status. The analysis shows that academic staff spent more time on the Internet than students and research

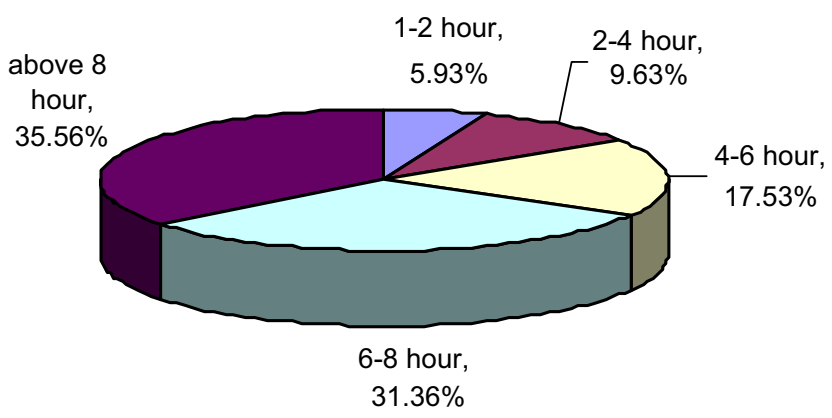

Figure 3 Time spent on the Internet each week.

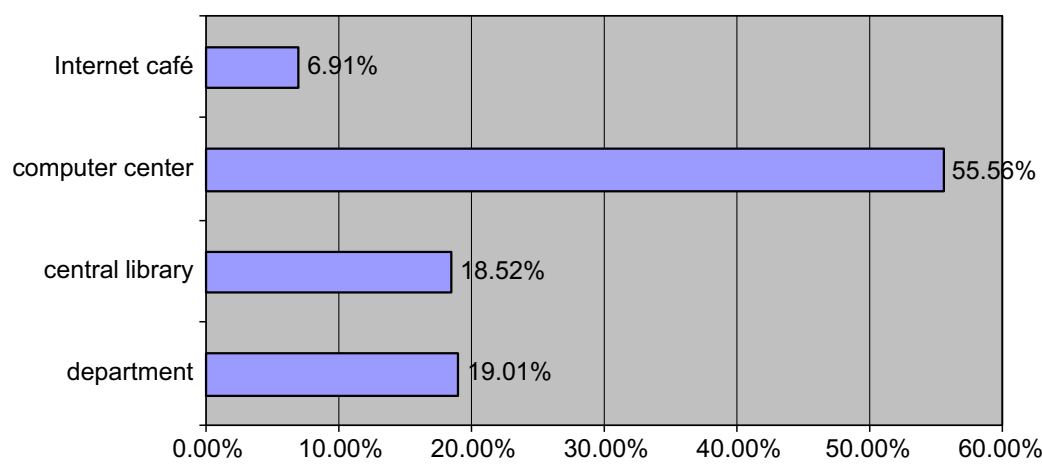

Figure 2 Location of Internet use.

Table 3 Location of Internet use (by academic status).

\begin{tabular}{lcccc}
\hline Academic status & Department & Central library & Computer center & Internet cafe \\
\hline Students $(n=201)$ & 9.45 & 24.38 & 56.21 & 9.95 \\
Research scholars $(n=102)$ & 16.67 & 20.58 & 57.84 & 4.90 \\
Academic staff $(n=102)$ & 40.20 & 4.90 & 51.96 & 2.94 \\
Average & 19.01 & 18.52 & 55.56 & 6.91 \\
\hline
\end{tabular}


scholars. About $50 \%$ of academic staff spent more than $8 \mathrm{~h}$ on the Internet each week while only $24 \%$ of students reached this level.

\section{Tools for searching information on the Internet}

In order to assess the information searching behavior of the Internet users, respondents were asked to indicate their preferred tools of searching information on the Internet. As Figure 4 shows, among different searching tools, search engines are the most commonly used tool reported by $88.06 \%$ of respondents. About 33\% of respondents searched information through the specific websites/URLs, whereas $18 \%$ used Internet gateways. However, $15 \%$ of respondents used databases to search for required information on the Internet.

Table 4 Time spent on the Internet per week (by academic status).

\begin{tabular}{lccccc}
\hline $\begin{array}{l}\text { Academic } \\
\text { status }\end{array}$ & $1-2 \mathrm{~h}$ & $2-4 \mathrm{~h}$ & $4-6 \mathrm{~h}$ & $6-8 \mathrm{~h}$ & $\begin{array}{l}\text { Above } \\
8 \mathrm{~h}\end{array}$ \\
\hline $\begin{array}{l}\text { Students } \\
(n=201)\end{array}$ & 9.96 & 11.44 & 18.41 & 38.81 & 24.38 \\
$\begin{array}{l}\text { Research } \\
\text { scholars } \\
(n=102)\end{array}$ & 5.88 & 8.82 & 16.66 & 25.49 & 36.27 \\
$\begin{array}{l}\text { Academic } \\
\text { staff } \\
(n=102)\end{array}$ & 3.92 & 6.86 & 16.66 & 22.55 & 50 \\
\begin{tabular}{l} 
Average \\
\hline
\end{tabular} & 5.93 & 9.63 & 17.53 & 31.36 & 25.56 \\
\hline
\end{tabular}

As Table 5 indicates, student respondents considered Internet search engines as the most important tools for searching information as compared to academic staff. Compared to the students, more research scholars and academic staff searched information through websites, Internet gateways and databases.

The analysis suggests that search engines are helpful tools to search the Internet for needed information within a short span of time, due to their user-friendly interface and availability at no cost.

\section{Search engines}

Respondents who searched for information through search engines were asked which search engine(s) they were most likely to use. A total of 325 respondents who searched information through the search engines were considered for the analysis. Details about the frequent usage of search engines among respondents are given in Table 6 . The findings revealed that Google and Yahoo were the most popular and widely used search engines among the respondents at $75.69 \%$ and $42.15 \%$, respectively. Other search engines, such as Altavista (28\%) took the third position and Scirus (24\%) fourth. Msn and Answers.com showed a usage by respondents of $19 \%$ and $14 \%$, respectively. About $10 \%$ of respondents took an interest in Ask.com and only 4\% used Hotbot.com in searches.

While analyzing the use of search engines, it has been observed that Google, Yahoo and Altavista were widely used search engines among respondents as compared to others for the following reasons:

(1) Wide coverage and updated regularly.

(2) Fast in access.

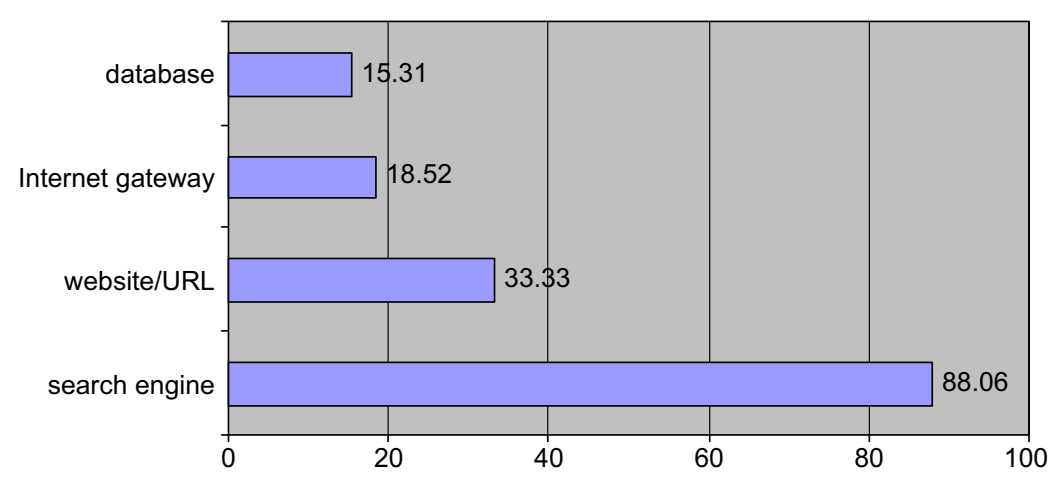

Figure 4 Internet search tools.

Table 5 Internet search tools (by academic status).

\begin{tabular}{|c|c|c|c|c|c|c|c|c|}
\hline \multirow[t]{2}{*}{ Academic status } & \multicolumn{2}{|c|}{ Search engine } & \multicolumn{2}{|c|}{ Website/URL } & \multicolumn{2}{|c|}{ Internet gateway } & \multicolumn{2}{|c|}{ Database } \\
\hline & Number & $\%$ & Number & $\%$ & Number & $\%$ & Number & $\%$ \\
\hline Students $(n=201)$ & 177 & 88.06 & 55 & 27.36 & 19 & 30.39 & 17 & 8.46 \\
\hline Research scholars $(n=102)$ & 81 & 79.41 & 33 & 32.35 & 25 & 24.51 & 19 & 18.63 \\
\hline Academic staff $(n=102)$ & 67 & 65.58 & 47 & 46.08 & 31 & 30.39 & 26 & 25.49 \\
\hline Average & 325 & 80.25 & 135 & 33.33 & 75 & 18.52 & 62 & 15.31 \\
\hline
\end{tabular}


Table 6 Use of search engines.

\begin{tabular}{|c|c|c|c|c|c|c|c|c|}
\hline \multirow[t]{2}{*}{ Search engine } & \multicolumn{2}{|c|}{ Students $(n=177)$} & \multicolumn{2}{|c|}{ Research scholars $(n=81)$} & \multicolumn{2}{|c|}{ Academic staff $(n=67)$} & \multicolumn{2}{|c|}{ Average $(n=325)$} \\
\hline & Number & $\%$ & Number & $\%$ & Number & $\%$ & Number & $\%$ \\
\hline Google.com & 137 & 77.40 & 61 & 67.90 & 48 & 71.64 & 246 & 75.69 \\
\hline Altavista.com & 47 & 26.55 & 25 & 30.36 & 19 & 28.35 & 91 & 28.00 \\
\hline Yahoo.com & 79 & 44.63 & 31 & 38.27 & 27 & 42.86 & 137 & 42.15 \\
\hline Scirus.com & 42 & 23.73 & 22 & 27.16 & 14 & 20.90 & 78 & 24.00 \\
\hline Ask.com & 11 & 6.21 & 11 & 13.58 & 9 & 13.43 & 31 & 9.54 \\
\hline Answers.com & 17 & 9.60 & 15 & 18.52 & 16 & 23.88 & 48 & 14.77 \\
\hline Msn.com & 38 & 21.46 & 13 & 16.04 & 11 & 16.42 & 62 & 19.08 \\
\hline Hotbot.com & 6 & 3.39 & 5 & 6.17 & 3 & 4.48 & 14 & 4.31 \\
\hline
\end{tabular}

Table 7 Kind of information sources.

\begin{tabular}{lcr}
\hline Information sources & Number & $\%$ \\
\hline Online journal & 287 & 70.86 \\
Database & 143 & 35.31 \\
Library catalogue & 58 & 14.32 \\
Statistical document & 79 & 19.51 \\
Reference document & 121 & 29.88 \\
Software & 92 & 22.72 \\
Government document & 33 & 8.15 \\
\hline
\end{tabular}

(3) Provide user-friendly interface.

(4) Provide links to websites world over.

(5) Separate interface for searching journals, images, news, audio, etc.

\section{Purpose of using Internet}

For the purpose of using the Internet, $73.08 \%$ of respondents answered that they use Internet for education and research, $46.42 \%$ for keeping abreast with the latest development in their specialized subjects and $28.88 \%$ for communicating with colleagues, academicians and editors of scholarly journals. About $21 \%$ of respondents indicated that they used the Internet for searching specialized information which they could not find in other sources, whereas $13 \%$ considered it a source of entertainment.

\section{Kind of information sources}

The survey also queried respondents to determine what kind of information sources they searched through the Internet. As Table 7 illustrates, online journals (70.86\%), databases (35.31\%) and reference documents $(29.88 \%)$ were the most frequently used information sources. The list of other kind of information sources, arranged by their percentage of users' responses, was software $(22.72 \%)$, statistical documents (19.51\%), library catalogues (14.32\%) and government documents $(8.15 \%)$.

\section{Internet services}

Respondents in the academic community accessed the Internet to obtain various services for education and research. As Figure 5 shows, e-mail was the most important service indicated by about $96 \%$ of respondents. The list of other services includes WWW (95.51\%), search engines (74.81\%), file transfer (45.92\%), frequently asked questions (33.83\%), chatting $(23.95 \%)$, discussion groups $(18.52 \%)$ and bulletin board services (14.57\%).

\section{Quality of Internet information}

With the availability of huge amounts of information through the Internet, it has become difficult to ascertain the quality and authenticity of such information. In response to the question of the quality of Internet information, a majority of respondents (59.93\%) believed that good quality information was available on the Internet and $23.90 \%$ respondents stated that the Internet provided excellent information. However, $6.16 \%$ of respondents were not satisfied with the average quality of information available through the Internet.

\section{Difficulties of accessing the Internet}

Though the Internet has become a common information source among the academic and research communities, the majority of the users of AMU stated that there are obstacles to use at times. The specific problems faced by the users are given in Table 8.

\section{Internet literacy}

Adams and Bonk (1995) found through a study that the most common obstacle for Internet users was their lack of knowledge about what was available and they argued for identifying alternatives to classes training in Internet use. Though AMU has not provided any formal training for Internet search, $17.51 \%$ respondents have stated that they have received training and $82.49 \%$ respondents stated that they have not undergone any training for Internet searches. To a further question as to whether they would like to receive training, $47.27 \%$ respondents said that they did not want any training and $52.63 \%$ replied in the affirmative. 


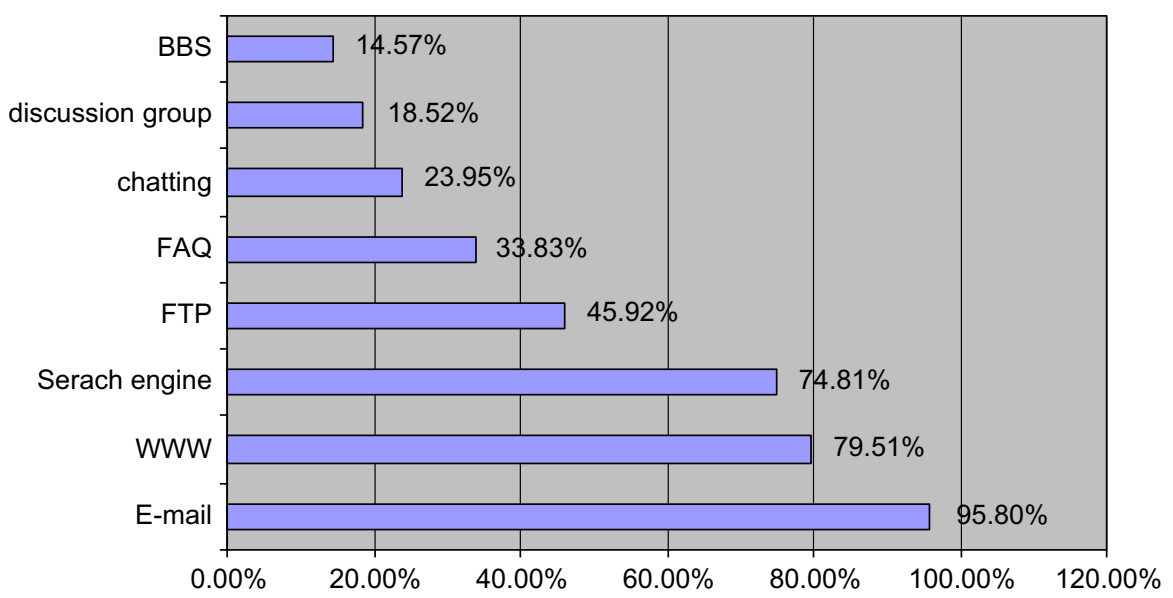

Figure 5 Internet services.

Table 8 Difficulties of accessing the Internet.

\begin{tabular}{lll}
\hline Difficulties & $\begin{array}{l}\text { Number of } \\
\text { respondents }\end{array}$ & $\%$ \\
\hline Slow speed & 195 & 48.15 \\
Information overload & 163 & 40.25 \\
Limited access terminals & 124 & 30.62 \\
Lack of training & 97 & 23.95 \\
Irrelevant information & 68 & 16.79 \\
Lack of organized & 59 & 14.57 \\
information & & \\
\hline
\end{tabular}

\section{Discussion}

This study evaluated information searching behavior of Internet users to find out their information search requirements, level of satisfaction with the Internet resources and problems which discouraged their use of the Internet. Following are the major findings of the study:

- Academic staff had a longer history of using the Internet than the students and research scholars. About 21\% academic staff had used the Internet longer than 5 years, whereas only $9 \%$ students had the same experience.

- Self-instruction was the best method of learning Internet usage. However, $32.35 \%$ of respondents learned to use the Internet through discussions with colleagues and friends.

- The computer center was the most comfortable place for accessing the Internet, where the majority of students and research scholars accessed the Internet for at least $1 \mathrm{~h}$ a day. Though academic staff had separate labs in the computer center with unlimited Internet access, only $50 \%$ staff visited the computer center.

- Majority of respondents spent at least $1 \mathrm{~h}$ on the Internet each day.

- Search engine was the most preferred tool for searching information on the Internet compared to other information searching tools of the Internet.
- Goggle and Yahoo were the most popular search engines among the Internet users of AMU.

- Majority of Internet users used the Internet for education and research purposes whereas $13 \%$ considered it as a source of entertainment.

- Online journals and databases were important information sources for the majority of the Internet users.

- About $60 \%$ of respondents believed that good quality information is available through the Internet.

- Slow speed, information overload and limited access terminals were some of the factors that affected respondents' use of the Internet.

- More than $50 \%$ of respondents made demands for Internet literacy programs for searching quality information.

\section{Conclusion}

In this new world of digital networked information, the library's mission to provide access to information will not fundamentally change but the means by which the mission is achieved has changed. The prediction of Ghikas (1989), 'the 21st century library collection will be an accumulation of information carriers both actual (locally owned) and virtual (electronic accessible)', has become a reality. The Internet revolution forces libraries and librarians to do something they have long dreamt of doing but have never been able to do. With the availability of Internet at minimum cost and efforts, it has become possible to access information from the entire global network. But researchers in developing countries like India are often not in a position to afford a personal computer with Internet access. Today, many users require assistance to know what information is available on the Internet, and also need assistance to access it effectively and economically. Library professionals can fill this role for the users of the Internet in the 21 st century just as they have filled this role for the users of printed information in the 20th century.

The present study corroborates the findings of similar studies indicating that the Internet has become an indispensable information source to the academic community. To 
further enhance Internet usage at $A M U$, the following measures should be taken:

- The number of computers with Internet connection in the computer center should be increased, since the majority of respondents mentioned that as their preferred place to access the Internet. Searching should be made available for at least $2 \mathrm{~h}$ for research scholars.

- The university library should subscribe to more online journals and databases in each discipline.

- Printout facilities should be provided with a nominal charge at the departments, central library and computer center.

- Librarians should take initiatives to prepare a list of subject websites that are useful for the researchers.

- Links to open access repositories, databases and online journals should be provided on the library's Web page.

- Library professionals on the campus should take initiatives to improve the information searching skills of Internet users by providing methodical training in order to improve the quality of information searching.

- The library should introduce an Internet literacy program.

\section{References}

Adams, Judith A., \& Bonk, Sharon C. (1995). Electronic information technologies and resources: Use by university faculty and faculty preferences for related library services. College and Research Libraries, 56(2), 119-131.

Akporido, C. E. (2005). Internet use in a Nigerian suburban setting. Electronic Library, 23, 302-310.

Asemi, A. (2005). Information searching habits of Internet users: A case study on the Medical Sciences University of Isfahan, Iran. Webology, 2 (1). Retrieved on May 5, 2006, from <http:// www.webology.ir/2005/v2n1/a10.html >.

Badu, E. E., \& Markwei, E. D. (2005). Internet awareness and use in the University of Ghana. Information Development, 21, 260-268.

Bavakutty, M., \& Salih, T. K. M. (1999). Internet services in Calicut University. In National convention on academic libraries in the Internet era (pp. 37-44), Organized by INFLIBNET, Ahmedabad, 18-20 February.

Becker, H. J. (1998). Internet use by teachers. Retrieved on June 26, 2004, from 〈http://www.crito.uci.edu/TLC/findings/InternetUse/startpage.html $\rangle$.
Chandran, D. (2000). Use of Internet resources and services in S.V. University, Tirupathi environment. In Conference on information services in a networked environment in India (pp. 3.124-3.127), Organized by INFLIBNET, Ahmedabad, 18-20 December .

Chowdhury, G. G., \& Chowdhury, S. C. (2003). Introduction to digital libraries. London: Facet Publishing.

Ghikas, M. W. (1989). Collection development for the 21st century. Journal of Library Administration, 11(1/2), 119-135.

Igun, S. E. (2005). Users and Internet skills: A report from Delta State University, Abraka, Nigeria. Electronic Journal of Academic and Special Librarianship, 6(3), 5-15.

Kalichman, S. C., Weinhardt, L., Benotsch, E., Difonzo, K., Luke, W., \& Austi, J. (2002). Internet access and Internet use for health information among people living with HIV-AIDS. Patient Education and Counseling, 46, 109-116.

Kaur, A. (2000). Internet facility at GNDU: A survey. In National seminar on academic libraries in the modern era (pp. 119-124), Organized by IASLIC, Bhopal, 4-6 December.

Laite, B. (2000). Internet use survey: Analysis. Retrieved on May 21, 2004, from 〈http://www.ship.edu/ bhl/survey/ >.

Mahajan, P. (2006). Internet use by researchers: A study of Punjab University, Chandigarh. Library Philosophy and Practice, 8(2), $1-4$.

Mahajan, S. G., \& Patil, S. K. (1999). Internet: Its use in university libraries in India. In National convention on academic libraries in the Internet era (pp. 483-488), Organized by INFLIBNET, Ahmedabad, 18-20 February.

Naushad Ali, P. M. (2000). Internet and its use in Aligarh Muslim University: A survey. In Conference on information services in a networked environment in India (pp. 1.78-1.82), Organized by INFLIBNET, Ahmedabad, 18-20 December.

Nazim, M., \& Chowdhary, A. H. (2004). Services using Internet and Intranet technology. In 49th all India library association conference on the responding to users' need in changing information landscape from palm-leaf to palmtop, ILA, Bundelkhand University, Jhansi.

Office of the Controller of Examination. (2006). Guide to admission 2006-07. Aligarh: Aligarh Muslim University.

Singh, D. (1998). The use of Internet among Malaysian librarians. Malaysian Journal of Library and Information Sciences, 3(2), 1-10.

Spink, A., Bateman, J., \& Jansen, B. J. (1999). Searching the Web: A survey of EXCITE users. Internet Research: Electronic Networking Applications and Policy, 9, 117-128.

Spink, A., \& Jansen, B. J. (2004). A study of Web search trends. Webology, 1 (2). Retrieved on May 5, 2006, from <http:// www.webology.ir/2004/v1n2/a4.html >.

Voorbij, H. (1999). Searching for scientific information on the Internet: A Dutch academic user survey. Journal of the American Society for Information Science, 50(7), 598-615. 